\title{
The Great Irish Famine in Songs
}

La Grande Famine irlandaise en chanson

\section{Erick Falc'her-Poyroux}

\section{(2) OpenEdition}

Journals

Electronic version

URL: http://journals.openedition.org/rfcb/277

DOI: $10.4000 / \mathrm{rfcb} .277$

ISSN: 2429-4373

\section{Publisher}

CRECIB - Centre de recherche et d'études en civilisation britannique

\section{Printed version}

Date of publication: 1 September 2014

Number of pages: 157-172

ISSN: 0248-9015

\section{Electronic reference}

Erick Falc'her-Poyroux, "The Great Irish Famine in Songs », Revue Française de Civilisation Britannique [Online], XIX-2 | 2014, Online since 01 May 2015, connection on 10 December 2020. URL : http:// journals.openedition.org/rfcb/277 ; DOI : https://doi.org/10.4000/rfcb.277

\section{(c) (i) (2) $\Theta$}

Revue française de civilisation britannique est mis à disposition selon les termes de la licence Creative Commons Attribution - Pas d'Utilisation Commerciale - Pas de Modification 4.0 International. 


\title{
The Great Irish Famine in Songs
}

\author{
Erick FALC'HER-POYROUX \\ Université de Nantes
}

\begin{abstract}
'Those in power write the history, those who suffer write the songs' Frank Harte (1933-2005), sleeve notes for 1798: the First Year of Liberty
\end{abstract}

However biased a view the opening quote by Irish traditional singer and collector Frank Harte may represent, an analysis of folk songs ${ }^{1}$ about the Great Irish Famine deserves careful study, as one will find in them views that are often told from palpable and vivid experience, and traces of Irish history often described as dry statistics, rather than the human tragedy it really was. It is generally considered that very few songs from the famine era have survived: it is indeed a testimony to the power and importance of traditional music and songs, and remarkably so in Ireland, that illiterate people on the threshold of exile or death could find the strength to express their misfortunes in such a poetic and elaborate form, as in this caoineadh (i.e. keen, or lament) by Peatsaí Ó Callanáin, a small tenant farmer from County Galway, in 1846:

Míle bliain agus ocht de chéadta,

Dhá fhichead gan bhréig is sé ina cheann

O'thuirling an Slanaitheoir i gcolainn daonna.

Go dtáinig Iénscrios ar fhataí an domhain.

Sin é an dáta is ní fath gan ábhar.

A mbeidh cuimhne is trácht air i gcaitheamh an tsaoil,

Mar níor tháinig uireasa dhá mhéad ar a cháilíocht

Is mó na ganntan is easpa an bhídh

TRANSLATION

One thousand years first and these eight hundred,

Two score most truly and six besides,

Since the Saviour took on him our human nature,

'Till the potatoes through the world died;

That is the date and we'll long remember,

${ }^{1}$ Although definitions may vary, the word 'folk' can be used as an equivalent to 'traditional'. In this article I will follow the definition decided upon at the Sao Paulo conference of the International Folk Music Council in 1954: 'Folk music is the product of a musical tradition that has been evolved through the process of oral transmission. The factors that shape the tradition are: (i) continuity which links the present with the past; (ii) variation which springs from the creative impulse of the individual or the group; and (iii) selection by the community, which determines the form or forms in which the music survives.' 
For 'twill be talked of for many a day,

For no disaster before was heard of

Which took like that all our food away. ${ }^{2}$

Oral tradition and history are often perceived as not working well together, as memories tend to blur and succeeding generations tend to choose what they wish to remember, thus rewriting history. ${ }^{3}$ This article proposes to examine representative items from this body of songs dating from the Great Irish Famine, in Irish and in English, in order to investigate their validity as faithful representations of History and understand why they are so elusive today, whether in public performances or in private circles.

\section{A musical context}

Ireland has had an exceptional musical reputation for centuries, and a refined instrument, the harp, has served as its national symbol since at least the thirteenth century. Even in the poorer classes, music was an important part of Irish everyday life, as evidenced by the accounts left to us by numerous witnesses, mostly from the eighteenth century onwards:

All the poor people, both men and women, learn to dance, and are exceedingly fond of the amusement. A ragged lad, without shoes or stockings, has been seen in a mud barn, leading up a girl in the same trim for a minuet: the love of dancing and musick are almost universal amongst them. ${ }^{4}$

Two main genres of folk singing in Ireland will be encountered among Famine songs: the most ancient type, today called sean-nós, is specific to the island. It can be traced back to a bardic substrate and the medieval chanson courtoise, imported by Anglo-Normans after the $13^{\text {th }}$ century: a very discreet a capella tradition sung in Irish Gaelic, it is a slow and restrained narrative type of singing which blossomed during the $16^{\text {th }}$ century, and is regarded by many as the essence of Irish music: 'Without a sound knowledge of the sean-nós and a feeling for it a performer has no hope of knowing what is authentic and what is not'. ${ }^{5}$ One should however point out that the term sean-nós only appeared in 1904 when it was used to describe the singing competitions during the Oireachtas festival organised by the Gaelic League. The English title of the competition ('old style singing') was then simply translated

2 'Na Fataí Bána' ('The White Potatoes'), by Peatsaí Ó CALLANÁIN, literary translation by Thomas CHAPMAN, quoted by Cormac Ó GRÁDA, An Drochshaol: Béaloideas agus Amhráin, Baile Átha Cliath: Coiscéim, 1994.

${ }^{3}$ See Maura CRONIN, 'Oral History, Oral Tradition and the Great Famine', p. 233 in Christian NOACK, Lindsay JANSSEN and Vincent COMERFORD (eds), Holodomor and Gorta Mór: Histories, Memories and Representations of Famine in the Ukraine and Ireland, London: Anthem Press, 2012.

${ }^{4}$ Arthur YOUNG, Arthur Young's Tour of Ireland (1776-1779), ed. A. W. HUTTON, London: G. Bell \& Sons, 1892, p. 366.

${ }^{5}$ Tomás Ó CANAINN, Traditional Music in Ireland, London: Routledge \& Kegan Paul, 1978, p. 49. 
into Irish and became 'amhrán ar an sean-nós'. One should thus bear in mind that the designation emanates from English speakers, and that the tradition was never interrupted, remaining popular mainly in rural areas of the West.

It was probably this highly ornamented style of singing that Frederick Douglass, the African-American slave turned abolitionist, heard when he toured Ireland for two months in 1845, later writing about it in his memoirs, and comparing them to his childhood memories:

I have never heard any songs like those anywhere since I left slavery, except when in Ireland. There I heard the same wailing notes, and was much affected by them. It was during the famine of 1845-6 [...]. Nowhere outside of dear old Ireland, in the days of want and famine, have I heard sounds so mournful. ${ }^{6}$

The second and most popular type of folk singing today in Ireland, however, is a genre called 'ballad singing': it is a slightly later development which was extremely popular all over Europe and appeared in urban Ireland during the $17^{\text {th }}$ century, probably under the influence of Scottish settlers, mostly in the northern part of the island. It is generally sung in English and tells a story on the classic themes of love, money, drinking, emigration, but also on more political themes:

The ballad as it exists is not a ballad save when it is in oral circulation [...]. Defined in the simplest terms, the ballad is a folk-song that tells a story. [...] What we have come to call a ballad is always a narrative, is always sung to a rounded melody and is always learned from the lips of others rather than by reading. ${ }^{7}$

Poets of the Gaelic Order, the 'Hedge-school Masters', and itinerant musicians, originally treated this new genre with great disdain, ${ }^{8}$ but later contributed greatly to its propagation with the elaborate style of old Gaelic poetry.

Only a handful of folk songs can however be traced back to the demographic and cultural catastrophe brought about by the Great Famine, and it seems sensible to infer that the subject was generally avoided for decades among poorer people as it brought back too many sorrowful memories - who would like to be asked to sing a song about an event that decimated or drove to emigration 3 million people of your own country?

In Irish academic circles, the topic was also avoided for decades, and only seriously taken up in 1935, when the Irish Folklore Commission, preparing for the

${ }^{6}$ Frederick DOUGLASS, Narrative of the Life of Frederick Douglass, an American Slave: My Bondage, My Freedom, New York: Dover, 1855, chapter 6: $<$ books.google.fr/books?id=5 VdvEo0AyVUC\&pg=PT39> [retrieved May $\left.5^{\text {th }} 2014\right]$.

${ }^{7}$ Gordon H. GEROULD, The Ballad of Tradition [1932], New York: Galaxy Books, 1957, p. 3 .

${ }^{8}$ See for example the character of Owen McCarthy in Thomas FLANAGAN, The Year of the French, London: Arrow Books, 1989. 
first centenary in 1945, sent collectors around Ireland to gather as much information as possible from old people. On one occasion, the most prominent of them, Séamus Ennis, remarked how people still refrained from using the word 'famine': 'I spent the rest of my visit talking and writing about the Famine - or "Drochshaol" ['bad times'], as they still call it here all the time'. ${ }^{9}$ This denial lasted more or less until the end of the $20^{\text {th }}$ century, only phasing out very gradually: 'The Famine, until the 150-year commemoration from 1997, was not a part of Irish history or folklore prominent in public discussion. Indeed, an air of shame and denial characterized popular memory. ${ }^{, 10}$

\section{Songs in the Irish language}

A traditional song, often being the work of an anonymous or forgotten author, can naturally be regarded as the representative expression of a community; and, being still sung by subsequent generations, will have successfully passed the test of time. Its continuous handling down from generation to generation ensures that the feeling is an enduring one. One song in Irish which has been carefully passed on since the mid-nineteenth century, is called 'Amhrán na bPrátaí Dubha' ('The Song of the Black Potatoes') ${ }^{11}$ and was probably composed during the Great Famine by Máire Ní Dhroma, who lived near Dungarvan.

It features ten verses, and is mostly an appeal to mercy from God: 'A Dhia na Glóire fóir agus freagair sinn' ('O God of glory protect us and answer us'), initially substantiating the belief expressed by many that the famine was a divine intervention, as openly stated by C.E. Trevelyan, the assistant secretary to HM Treasury, and in effect the general administrator of relief programmes in Ireland during that period:

I hope I am not guilty of irreverence in thinking that, this being altogether beyond the power of man, the cure has been applied by the direct stroke of an all-wise Providence [...]. God grant that we may rightly perform our part, and not turn into a curse what was intended for a blessing. ${ }^{12}$

As this was also the view supported by the Catholic clergy in Ireland, 'Amhrán na bPrátaí Dubha' stands out as a strongly discordant voice, with a tone of social and political protest summed up in one line of the song, where faith gives way to a passionate objection: 'Ní hé Dia a cheap riamh an obair seo, Daoine bochta a chur le fuacht is le fán' ('It wasn't God's work, sending out poor people to cold and

${ }^{9}$ Séamus ENNIS, May 5, 1945, Going to the Well for Water: The Séamus Ennis Field Diary 1942-1946, transl. and ed. by Ríonach UÍ ÓGÁIN, Cork: Cork University Press, 2009, p. 242.

${ }^{10}$ Lillis Ó LAOIRE and Sean WILLIAMS, 'Singing the Famine: Joe Heaney, "Johnny Seoighe" and the Poetics of Performance', pp. 231-232 in A. CLUNE (ed.), Dear Far-Voiced Veteran: Essays in Honour of Tom Munnelly, Miltown: Malbay, 2007.

${ }^{11}$ The song appears on several CDs, among others: Áine UÍ CHEALLAIGH, Isir Dhá Chomhairle (Gael Linn, 1992); and Nioclás TÓIBÍN, Rinn na nGael (Cló Iar-Chonnachta, 1999).

${ }^{12}$ Letter of Charles Trevelyan to Thomas Spring-Rice (Lord Mounteagle), 9 October 1846. 
wandering'). This line, which has more recently been used on several memorials to the Great Famine victims, from Limerick to Melbourne, could explain why the song was very rarely heard until the mid- $20^{\text {th }}$ century. A similarly angry song in Irish, highly critical of the clergy itself, is 'An Bhuatais', the story of a Catholic priest who preferred to buy himself new boots rather than take care of his dying parishioners. ${ }^{13}$ Understandably, this song was also very rarely heard in Ireland before the second half of the 20th century. More common, however, was the criticism against the system of the poorhouses and the organisation of the relief system, also mentioned in 'Amhrán na bPrátaí Dubha': 'Iad a chur sa phoorhouse go dubhach is glas orthu [...] Ar bheagán lóin ach soup na hainnise' ('Locked in a gloomy and grey poorhouse [...] with but a little soup of misery').

But nowhere is this criticism more bitterly expressed than in 'Johnny Seoighe', a satirical song in the refined allusive poetic tradition of Ireland, which can only be fully understood if one hears the accompanying scéal, the story traditionally told by the singer before singing: on Christmas Eve, the author (probably Tomás Shiúnach from Carna, in Connemara) and his family walked all the way to the workhouse only to find they couldn't be accepted there for lack of space. They then asked the famine relief officer, Johnny Joyce (Seoighe, in Irish), for help and food, which was denied, and his wife and children subsequently died on the way back home from hunger and exhaustion. One can hardly imagine the grief that led to those subtly sarcastic and angry lines:

Is a Johnny Seoighe, tuig mo ghlórtha 'S mé ag tíocht le dóchas faoi do dhéin Mar is tú an Réalt Eolais is deise lóchrann As mo shúil ag teampall Dé [...]

Tá mé bruite dóite sciúrtha feannta Liobraithe gearrtha le neart den tsiúil Gus a mhister Joyce tá an workhouse lán is ní ghlacfar ann isteach níos mó

TRANSLATION

Johnny Joyce hear my voice

I come to you full of hope

As you are the most beautiful Star of Knowledge

A beacon in the temple of God [...]

I am burnt, battered and stripped

Soaked and cut with so much walking.

And Mister Joyce the workhouse is full

And no one is taken in any more. ${ }^{14}$

\footnotetext{
${ }^{13}$ Available on Áine UÍ CHEALLAIGH's CD Isir Dhá Chomhairle (Gael Linn, 1992) and Frank HARTE and Dónal LUNNY's The Hungry Voice: The Song Legacy of Ireland's Great Hunger (Hummingbird, 2004).

14 Available on TRIAN's eponymous first album (Flying Fish, 1992). It has also been included on a 'Celtic Christmas' music compilation by uninformed executives of a major US company.
} 
Here again, this song was long regarded as taboo, and kept well within the Carna community, until it started being sung in public in the late 1950s by sean-nós Connemara singer Seán Mac Dhonnchadha, who remembered 'being publicly criticised for singing this song in the Damer Hall in Dublin at the Oícheanta Seanchais concerts organized by [the state-funded company] Gael-Linn in the late fifties and early sixties'. ${ }^{15}$ The exact reasons remain unclear, as the scéal (story) is now partly missing, and the irony thus remains partly lost, but it would seem that Johnny Seoighe was a shady character of dubious morals. ${ }^{16}$ It is generally difficult to know in which circumstances a traditional song was created, but in this case, specific events and folk memory handed down orally from generation to generation give us a different approach from history books about the origins and conditions in which the destitute were living. Another example from Connemara is a song called 'Soup house Mhuigh-Iorrais', which includes one of the very rare descriptions of the effects of hunger: 'Níl duine ar bith sách láidir ag an ocras ach aon lá amháin, scaipeann sé na cnámhaí agus leaghann sé an fheoil' ('Nobody is strong enough to endure hunger for a day, it slackens the bones and dissolves the flesh').

It is quite remarkable that so few folk songs in Irish about the Great Famine have survived, given its huge impact on Irish history and the very high number of Irish-speakers at the time: economist and historian Cormac Ó Gráda suggests 'an Irish-speaking figure of 3-3.5 million on the eve of the famine, an all-time high' ${ }^{17} \mathrm{It}$ has however often been remarked that hunger silenced the country for a prolonged period of time after 1849: in some areas, mostly in the South and the West of Ireland, no human being could be heard and no living animals could be seen for miles. George Petrie, a noted collector of music from the people, expressed his nostalgia in the introduction to his 1855 volume of The Ancient Music of Ireland:

The green pastoral plains, the fruitful valleys, as well as the wild hillsides and the dreary bogs, has equally ceased to be animate with human life. The 'land of song' was no longer tuneful; or if a human sound met the traveller's ear, it was only that of the feeble and despairing wail for the dead. This awful unwonted silence, which during the famine and subsequent years, almost everywhere prevailed, struck more fearfully on their imaginations, as many Irish gentlemen informed me, and gave them a deeper feeling of the desolation with which the country had been visited, than other circumstances which had forced itself upon their attention. ${ }^{18}$

Gradually, Ireland's countryside ceased to be a vibrant source of music and dancing, especially in the Irish-speaking areas, the Gaeltachtaí, the poorer parts of Ireland. A traditional song from County Kerry recalls the sudden changes in the atmosphere of the countryside:

${ }^{15}$ Ó LAOIRE and WILLIAMS, 'Singing the Famine', op. cit., p. 231.

${ }^{16}$ See Cormac Ó GRÁDA, Black ' 47 and Beyond: The Great Irish Famine in History, Economy, and Memory, Princeton University Press, 2000, pp. 218-219.

${ }^{17}$ Ibid., p. 216.

${ }^{18}$ George PETRIE, The Ancient Music of Ireland, Vol. 1, Dublin: Society for the Preservation and Publication of the Melodies of Ireland, 1855, p. 21. 
Ní bheidh in Éirinn ach daoine aosta

I mbun stoic ag aoireacht cois fallaí $i$ ndrúcht;

Ní bheidh pósadh in aon bhall ná suim ina dhéanamh,

Ach 'tabhair dom an spré' agus 'rghad anonn'.

TRANSLATION

Only the elderly will remain in Ireland

Minding livestock by the walls in the dew;

There will be no marriages, nor interest in them,

But 'give me the dowry' and 'I'll head off' 19

One more reason for the probable disappearance of many folk songs in Irish can also be perceived when one realises that collectors of the eighteenth and nineteenth centuries did not take down the texts they heard in Irish, as the language of the peasantry was often regarded as dead, or not delicate enough for educated ears. They often substituted their own poems to the original words and, where they did not, we must content ourselves with a title and a melody, which was itself often modified to suit the taste of the time. ${ }^{20}$

\section{Songs in the English language}

The new tradition which started expanding on the ashes of the evicted cottages in the late 1840s was now more likely to be in English, but these new compositions were very different from the previous body of folk songs in Irish, with their highly elaborate style in sound and rhythm, inherited from the bardic tradition and later passed on by the schoolmasters and poets of the $17^{\text {th }}$ and $18^{\text {th }}$ centuries. There doesn't seem to have been a general tendency to translate songs from one language to the other, as underlined by Breandán Breathnach, one of the leading authorities on Irish music in the $20^{\text {th }}$ century: 'The decline of the language involved the rejection of the body of folk-song which had its existence in it. [...] there is an innate relationship between folk-song and language which inhibits adoption by way of translation. 21

Irish scholar Donal O'Sullivan summed up the consequences in one of the earliest studies of Irish music in modern times: 'It is indeed, indicative of the profound effect of the change of language on the national character and psychology. The poetic fancy, choice diction and variety of themes [...] - all these have disappeared, and the words are too often an ill match for the airs in terms of beauty'. ${ }^{22}$

${ }^{19}$ Quoted by Ó GRÁDA, Black' 47 and Beyond, op. cit., p. 226.

${ }^{20}$ An obvious and world-famous example is the melody for 'Danny Boy', originally collected from an itinerant piper in Limavady, Northern Ireland, by Jane Ross, without a name and without words. The melody as printed in George Petrie's 1855 volume 1 of The Ancient Music of Ireland offers such a wide compass that it can safely be considered as having been modified to bring it closer to art music than to folk singing.

${ }^{21}$ Breandán BREATHNACH, Folk Music and Dances of Ireland, Cork: The Mercier Press, 1971, pp. 29-31.

${ }^{22}$ Donal O'SULLIVAN, Irish Folk Music, Song and Dance [1952], Cork: The Mercier Press $\&$ the Cultural Relations Committee, 1969, p. 47. 
While Irish folk songs tended to reflect on events supposedly known by all in the community, ballads in English were more inclined to describe a similar event chronologically and systematically. The trend was not completely new, however, especially in urban centres like Dublin or Cork, where the ballads in English coming from London had slowly grown in popularity since the $17^{\text {th }}$ century.

Used by Theobald Wolf Tone and the United Irishmen at the end of the $18^{\text {th }}$ century, street ballads grew further in popularity after the Napoleonic wars (18031815) and, in Ireland, thanks to early nationalist militants seeking to advance their claims of independence. Charles Gavan Duffy, founder and editor of the newspaper The Nation, in particular, asked his readers to compose new ballads in the political vein between 1842 and 1845. Among the 800 new songs that were printed in the newspaper, some of them ('A Nation Once Again', 'The West's Awake', ...) can still be heard today in certain circles. They should however be considered as representative of the views of the urban nationalist political elite rather than the expression of the people, and often convey what has been termed 'social distance':

many of the Ballads [of The Nation] are in the imperative, such as 'Bide your Time' and 'Be Patient', or a ballad would have a moral to it, such as 'Aid Yourself and God will Aid You'. Here, The Nation is talking down to, rather than singing with the people, and we are conscious of its implicit feeling of superiority. ${ }^{23}$

The mid $-19^{\text {th }}$ century understandably witnessed a genre mixing both the Irish and English languages, referred to as 'macaronic' songs, where English generally prevails over Irish Gaelic, which was sometimes used in a veiled and subversive way, and more recently as a sprinkling of 'Irishness' in parlour songs.

The term 'macaronic', probably from Italian 'macaroneo' (burlesque poem), originally meant a poetic parody merging a vernacular language to Latin and, by extension, any international language. In Ireland, it was indeed a common feature of folk songs, particularly in Munster, to have Irish and English words mixed in the same sentence or the same verse, and this is probably another legacy of the Gaelic poets. The following is a later and slightly clichéd example, from 'The Potato Digger's Song' about a man digging potatoes: 'Come, Connal, acushla, turn the clay, And show the lumpers the light, gossoon!', where 'acushla' is a hackneyed Irish expression, from Irish Gaelic 'a cuisle' ('oh, darling!'), and 'gossoon' means 'boy' (from French, 'garçon'). Another song about potatoes, still sung today, is called 'The Praties They Grow Small' (a.k.a. 'The Famine Song'), from Irish Gaelic 'prataî', meaning 'potatoes'. And yet another popular famine song is 'Dan O'Hara', whose chorus is a deceptively joyful and rhyming 'A Cuisle Geal Mo Chroí / Won't you buy a box from me', where 'Geal Mo Chrô' is also a clichéd exclamation meaning 'brightness of my heart' or 'my beautiful sweetheart'. The underlying grief is, once again, only perceived when the 'sceal' of the song is told: although the song was probably written by Delia Murphy from Claremorris in 1951, Dan O'Hara was a real tenant farmer from Clifden, Connemara, who was evicted from his farm and

${ }^{23}$ Desmond KENNY, 'The Ballads of The Nation', Cahiers du Centre d'Etudes Irlandaises, $\mathrm{N}^{\circ}$ 3, Rennes: PUR, 1978, p. 43. 
forced to emigrate to America as he couldn't pay the rent. Unfortunately, no official figures are available for evictions before 1849, when 90,000 thousand of them were recorded by the constabulary, the figure rising to 100,000 in 1850 . The traditional song 'Shamrock Shore' relates the rage that sometimes led to retaliation by secret societies like the Ribbon Men, the White Boys or the Molly Maguires, and sometimes to the murdering of landlords ${ }^{24}$ :

All by those cursed tyrants we are forced for to obey
Some haughty landlords for to please
Our houses and our lands they'll seize
To put fifty farms into one and take us all away
Regardless of the widow's cries
The mother's tears and the orphan's sighs ${ }^{25}$

Probably the most famous eviction song, however, is 'Lough Sheelin' (or 'Lough Sheelin Side'), named after the lake bordering the counties of Cavan, Meath and Westmeath. It recounts the mass eviction of small cottiers and their families in Tonagh, Co. Meath, a hundred kilometres north-west of Dublin. Differing versions of this anonymous song abound today, but all describe how 700 people were thrown out of their houses on a cold day:

But our good dreams were too good to last

The landlord came our home to blast

And he no mercy on us did show

As he turned us out in the blinding snow

No one dare open for us their door

Or else his vengeance would reach them sure;

My Eileen fainted in my arms and died

As the snow lay deep on the mountainside. ${ }^{26}$

Strikingly, this is more than likely the very eviction that was witnessed by a young priest who, years later, as Bishop Thomas Nulty, described in a long pastoral letter to the clergy of his diocese of Meath the consequences of the landlords' desire to reorganise the use of their land:

Seven hundred human beings were driven from their homes in one day and set adrift on the world, to gratify the caprice of one who, before God and man, probably deserved less consideration than the last and least of them. [...] The horrid scenes I then witnessed, I must remember all my life long. The wailing of women - the screams, the terror, the consternation of children - the speechless agony of honest

${ }^{24}$ On November $2^{\text {nd }} 1847$, Denis Mahon of Strokestown House, Co. Roscommon was the first landlord to be murdered during the Great Famine after evicting 3000 persons. His 'big house' (as landlords' stately homes are called in Ireland) is now home to a Great Famine museum, which opened in 1994.

${ }_{25}$ 'The Shamrock Shore', available on the album Molloy Brady Peoples, Mulligan, 1978.

${ }^{26}$ Available on the charity album CD Araglen Album, sung by Con G. Leddy, 2002. And online $<$ youtu.be/NuvAZfluKF8 $>$ [retrieved May $10^{\text {th }} 2014$ ]. 
industrious men - wrung tears of grief from all who saw them. I saw officers and men of a large police force, who were obliged to attend on the occasion, cry like children at beholding the cruel sufferings of the very people whom they would be obliged to butcher had they offered the least resistance. The landed proprietors in a circle all aroundand for many miles in every direction - warned their tenantry, with threats of their direct vengeance, against the humanity of extending to any of them the hospitality of a single night's shelter. [...] and in little more than three years, nearly a fourth of them lay quietly in their graves. $^{27}$

Indeed, many small farmers, evicted from their plot of land, denied visible help by their neighbours, and unable to pay for a passage to England or America, died of hunger or, even more often, of scurvy, typhus or relapsing fever.

Songs based on true stories and related by amateur poets are plentiful in street balladry, whether anonymous or signed, and the following is another popular song about eviction written by Irish revolutionary and eminent member of the Irish Republican Brotherhood Charles Joseph Kickham on reading in the newspapers about the real story of Patrick Sheehan: ${ }^{28}$

My father died, I closed his eyes outside our cabin door;

The landlord and the sheriff too were there the day before.

And then my loving mother, and sisters three also,

Were forced to go with broken hearts from the Glen of Aherlow. ${ }^{29}$

\section{Emigration}

One aspect common to these two songs, and of many others in the same vein of Irish ballads, is the powerful 'sense of place' which is displayed. It is a common feature of many compositions of Irish literature, from Ó Dubhgáin's $14^{\text {th }}$-century 'Topographical poems' to Aodhagán Ó Rathaille's $18^{\text {th }}$-century deathbed poem 'Cabhair Ní Ghairfead' ('I'll Not Ask for Help'), on to William B. Yeats exclaiming about John Synge: 'that rooted man'30 and, more recently, Séamus Heaney's 1975 poem collection North, Brian Friel's 1980 play Translations, or Ciarán Carson's 1987 poem 'Turn Again'. In his essay 'The Sense of Place', Nobel laureate Séamus Heaney explained the profound link between displacement and what Patrick Sheeran has called topomania in Ireland:

\footnotetext{
${ }^{27}$ Pastoral letter dated 20th February, 1871, by Dr. Thomas Nulty, Bishop of Meath, Report from the Select Committee on Westmeath, \&c. (Unlawful Combinations); together with the proceedings of the committee, minutes of evidence, and appendix, House of Commons Parliamentary Papers, 1871.

28 'The Glen of Aherlow' was first published in The Kilkenny Journal, on 7 October 1857 under the pseudonym 'Darby Ryan, Junior'.

${ }^{29}$ Available on Joe Heaney's album Road from Connemara, 2000.

${ }^{30}$ William Butler Yeats, 'The Municipal Gallery Revisited', 1937.
} 
It is this feeling, assenting, equable marriage between the geographical country and the country of the mind, whether that country of the mind takes its tone unconsciously from a shared oral inherited culture, or from a consciously savoured literary culture, or from both, it is this marriage that constitutes the sense of place in its richest possible manifestation. ${ }^{31}$

The passing down from one generation to the other of a memory of places via their names is generally regarded as a direct legacy of the Gaelic Order. Where history had barred Catholic owners from their own property and a sense of belonging, they made use of the only tangible feature that was still theirs - names of places in Gaelic Irish - as a way of identifying with space, marking their territory, and virtually regaining their lost possessions. And this feeling had been further exacerbated by the completion of the Ordnance Survey maps, drawn up between 1822 and 1824, and which had chiefly replaced Irish names by English approximations. $^{32}$ In this context, eviction was regarded as the penultimate punishment, only second to exile. In a debate at the House of Lords in 1845, Lord Stanley was thus able to remark:

if there be anything like compulsion in the emigration, it becomes an act of tyranny and oppression; and, under the most favourable circumstances, the warm attachment of the Irish peasant to the locality in which he was born and brought up will always make the best and most carefully conducted system of emigration, a matter of painful sacrifice on the part of the emigrant, involving to a large and painful extent his personal and domestic feelings. ${ }^{33}$

The word used today for voluntary emigration in Irish Gaelic is eisimirce, but it was not in use until the beginning of the $20^{\text {th }}$ century. Up until then, and naturally during the Great Famine, the only word ever used was deoraí, meaning 'exile'. ${ }^{4}$ Reluctant exile, or emigration, was not a new phenomenon in the 1840 s, but the departure from home became the lot of thousands of poor Irish families every month, a forced path to escape misery or death, as described in Lone Shanakyle, named after the mass burial pit that served as a graveyard in Kilrush, Co. Clare:

Sad, sad is my fate in this weary exile

Dark, dark is the night cloud o'er lone Shanakyle

Where the murdered sleep silently pile upon pile

In the coffinless graves of poor Éireann ${ }^{35}$

\footnotetext{
${ }^{31}$ See Séamus HEANEY, 'The Sense of Place', p. 132 in Preoccupations, Selected Prose, 1968-1978, London: Faber and Faber, 1980.

${ }^{32}$ See for example the play Translations by Brian FRIEL, London: Faber \& Faber, 1980.

${ }^{33}$ Lord Stanley, Compensation to Tenants (Ireland) Bill, House of Lords debate, June $9^{\text {th }}$ 1845, Hansard, vol. 81, cc. 211-35, p. 212.

${ }^{34}$ See John MOULDEN, Thousands are Sailing: a brief song history of Irish emigration, Portrush: Ulstersongs, 1994, and Mick MOLONEY, Far from the Shamrock Shore: The Story of Irish-American Immigration Through Song, Cork: Collins Press, 2002.

${ }^{35}$ Available on DÉANTA's album Whisper of a Secret, 1997. The song was written by Thomas Madigan (1797-1881).
} 
If you ask any Irish person today what the most famous Famine song is, it is very likely you will hear the name of a small town in Co. Cork: Skibbereen. Between 1845 and 1850, 9,000 men, women and children were buried in the nearby common graveyard at Abbeystrewery during the Great Famine. The song was probably written by Patrick Carpenter, and is a bitter and vengeful reminder of those days in the form of a discussion between a son and his father:

Father, dear, I often hear you speak of Erin's Isle.

It seems so bright and beautiful, so rich and rare the soil.

You say it is a bounteous land wherein a prince might dwell.

Then why did you abandon it? The reason to me tell. [...]

It's well I do remember the year of forty-eight,

When we arose with Erin's boys to fight against our fate;

I was hunted through the mountains as a traitor to the Queen,

And that's another reason that I left Old Skibbereen.

As more and more Irish men and women emigrated to America, news started to flow more regularly between the two sides of the Atlantic and the temptation to leave was doubtless hard to resist: 'So pack up your sea-stores, consider no longer, for ten dollars a week isn't very bad pay, with no taxes or tithes to devour up your wages ${ }^{36}$ Very often, a son or a daughter in the family would be chosen to emigrate and money was gathered for the passage ticket, in the hope that it would soon be reimbursed by his or her wages in America. Later, he or she might also pay for the passage of a second member of a family, etc.

Starting from the period of the Great Famine, departures were generally celebrated during an evening of praying, music, story telling and dancing, called the 'American wake'. Leaving the country was generally regarded on a par with death, as very few exiles ever returned home:

The night before leaving they are bidding goodbye And it's early next morning their heart gives a sigh They do kiss their mothers and then they do say

Fare thee well, dearest father, we must now go away Their friends and relations, their neighbours also When the trunks they are packed up all ready to go The tears from their eyes they fall down like the rain And the horses are prancing going off for the train. ${ }^{37}$

The following extract by English sociologist and novelist Harriet Martineau confirms the poignancy of such scenes, as witnessed in Castlebar, Co. Mayo in 1852, where the keening for the departed took place:

All eyes were fixed on the neighbours who were going away for ever. The last embraces were terrible to see; but worse were the kissings

36 'The Green Fields of Canada' (a.k.a. 'The Green Fields of America' or 'Amerikay'). Available on DÉANTA's eponymous first album, 1993.

37 'Thousands are Sailing', available on DÉANTA's first album, op. cit. 
and the claspings of the hands during the long minutes that remained after the woman and children had taken their seats. [...] there it was, the pain and the passion: and the shrill united cry, when the car moved on, rings in our ears, and long will ring when we hear of emigration. ${ }^{38}$

The dangers of the crossing on the cheap 'coffin ships' are also vividly documented in many songs, as in the following extracts, where typhus is illustrated:

We were scarcely seven days at sea when the fever, it plagued our crew They were falling like the autumn leaves bidding friends and life adieu Now the raging waves sweep o'er their graves amidst the ocean foam Their friends may mourn, but they'll never return to Erin's lovely home

My loving sisters, they both took ill, their lives, they were taken away And oh it grieved my heart full sore to cast them in the sea Down in the deep now they do sleep, they never more will roam In heaven I'll meet with my sisters sweet from Erin's lovely home ${ }^{39}$

Finally, songs about the arrival and the settling down in America or in England abound in Irish balladry, and can be split into two broad categories: cheerful illustrations of a happier life as in the above mentioned 'Green Fields of Canada' and countless others, or the distressed expression of nostalgia and/or regrets as in 'Paddy works on the Railway': 'I was wearing corduroy britches, digging ditches, pulling switches, dodging hitches, I was workin' on the railway, [...] I'm weary of the railway, poor Paddy works on the railway. ${ }^{40}$ In an important footnote for his recent study Music in Irish Cultural History summarising recent Irish history, historian Gerry Smyth could thus write: "One could argue that "dislocation" and "nostalgia" have been the principal impulses of Irish critical discourse since the Famine, ${ }^{41}$

Emigration has undeniably been one of the most important sources of inspiration for songs of the Irish repertoire during the $20^{\text {th }}$ century, and has even led to some of the most famous 'pseudo Irish' songs, including 'I'll Take You Home Again, Kathleen', still a favourite of Irish descendants the world over. ${ }^{42}$ One should therefore not take all emigration songs at face value, as many of them were written by would-be emigrants describing a foreign place they had never visited. In this respect, folklorist John Moulden was able to remark that emigration songs were sometimes more a construct by those who stayed in Ireland than the real feelings of

${ }^{38}$ Harriet MARTINEAU, Letters from Ireland, London: John Chapman, 1852, p. 140.

39 'Erin's Lovely Home', available on KARAN CASEY'S album Ships in the Forest, 2008.

40 'Poor Paddy works on the Railway', in MOLONEY, Far from the Shamrock Shore, op. cit.

${ }^{41}$ Gerry SMYTH, Music in Irish Cultural History, Dublin: Irish Academic Press, 2009, p. 178.

42 'I'll Take You Home Again, Kathleen' was written in 1875 by Thomas P. Westendorf, a German-American who had never been to Ireland. It has since been used on almost every possible Irish nostalgic occasion. See for example John Ford's movie Rio Grande (1950), set in 1879, or a 1966 episode of Star Trek (The Naked Time), set in 2266. 
exiled Irish men and women. ${ }^{43}$ There remains that the events described in the previous pages and the forced exile undergone by Irish people during that period and since, have left unforgettable marks in the psyche of the Irish Diaspora and a strong bitterness that has been passed on from generation to generation, in particular in the USA.

\section{Conclusion}

The question of the Great Irish Famine remains a very sensitive one in Ireland today, and the opening quote by Frank Harte was a reminder of, not only the circumstances in which a song is created, but also of today's context in which it is experienced and received, how history is told, retold, and rewritten. Musicians and their audiences are, after all, members of a community and should be viewed as such. While they narrate the chronicles of the world surrounding them, songsters are also interpreting it: 'Most ballads are human (if not historical) documents, and the story told so straightforwardly in "Skibbereen", for example, certainly falls into that category ${ }^{44}$ It is thus self-evident that the songs concerned with the Great Famine and Irish emigration open the door to multiple uses and multiple interpretations by singers and listeners alike. But as Cormac Ó Grada has argued, songs can reasonably be regarded as avoiding this pitfall, and can emerge as credible records, 'fossilized like contemporary written documents, ${ }^{45}$ even if many of them, like all traditional songs, have given birth to slightly differing versions in the decades that followed.

The sufferings of Ireland between 1845 and 1850 could however hardly be overestimated, and the effects can still be felt in everyday life after more than 150 years: with well over 8 million inhabitants on the island in 1841 and a little under 6.5 million today, Ireland is the only place in Europe whose population has decreased since the 1840s. By comparison, the population of England (c. 13.6 million in 1841) has almost quadrupled, to c. 53 million today. ${ }^{46}$

From Bob Geldof's reaction to the 1984 famine in Ethiopia and the subsequent monster Live Aid concerts on both sides of the Atlantic, to the funding of the IRA in the USA via Noraid and Clan na Gael up until 9/11, and to the enduring position of Ireland as the second most generous country in the world in charity donations, behind the USA ${ }^{47}$ there is ample evidence of the far reaching consequences of the five years of 'Drochshaol' ('Bad Times').

If many of the poignant songs mentioned in this study are rarely sung or heard in unfamiliar settings, one should probably blame the sadness associated with the memories, the implication of local names in many personal stories, and the weight

${ }^{43}$ See John MOULDEN, The Printed Ballad in Ireland: A Guide to the Popular Printing of Songs in Ireland 1760-1920, Ph.D. thesis, Galway: National University of Ireland, 2006, p. 390 .

${ }^{44}$ Herbert HUGHES, Irish Country Songs, preface to volume 2, London: Boosey and Hawkes, 1915.

${ }^{45}$ Ó GRÁDA, Black '47 and Beyond, op. cit., p. 217.

${ }^{46}$ Figures available on: <www. statistics.gov.uk > [retrived May 19 ${ }^{\text {th }}$ 2014].

47 For details, see the World Giving Index: <www.cafonline.org/publications/2013publications/world-giving-index-2013.aspx $>$ [retrieved May $19^{\text {th }} 2014$ ]. 
of the Roman Catholic Church. In turn, this amputation of a common memorial legacy led to the feeling that the Irish peasantry had been robbed of its last possessions: the sense of belonging, leading to the worst of sanctions - exile. In oral tradition however, the popular aphorism still remembers that 'even the birds were silent with grief' during the Great Famine.

\section{Bibliography}

BREATHNACH, Breandán. Folk Music and Dances of Ireland. Cork: The Mercier Press, 1971, 152 pp.

CRONIN, Maura. 'Oral History, Oral Tradition and the Great Famine', pp. 231-244 in Christian NOACK, Lindsay JANSENN and Vincent COMERFORD (eds), Holodomor and Gorta Mór: Histories, Memories and Representations of Famine in the Ukraine and Ireland, London: Anthem Press, 2012.

CROWLEY, John, SMYTH, William J., and MURPHY, Mike (eds). Atlas of the Great Irish Famine. New York: NYUP, 2012, 710 pp.

ENNIS, Séamus. Going to the Well for Water: The Séamus Ennis Field Diary 19421946, transl. and ed. Ríonach UÍ ÓGÁIN. Cork: University Press, 2009, 595 pp.

FLANAGAN, Thomas. The Year of the French. London: Arrow Books, 1989, 642 pp.

FRIEL, Brian. Translations. London: Faber \& Faber, 1980, 70 pp.

GEROULD, Gordon H. The Ballad of Tradition [1932]. New York: Galaxy Books, $1957,311 \mathrm{pp}$.

HEANEY, Séamus. 'The Sense of Place', pp. 131-149 in Preoccupations, Selected Prose, 1968-1978, London and Boston: Faber and Faber.

HUGHES, Herbert. Irish Country Songs, preface to volume 2. London: Boosey and Hawkes, 1915, 120 pp.

KINEALY, Christine. This Great Calamity: The Irish Famine, 1845-52. Dublin: Gill \& Macmillan, 2006 (2nd ed.), 480 pp.

KENNY, Desmond. 'The Ballads of The Nation', Cahiers du Centre d'Etudes Irlandaises, $\mathrm{N}^{\circ}$ 3, Rennes: PUR, 1978, pp. 31-45.

LAXTON, Edward. The Famine Ships: The Irish Exodus to America. Boston: Holt McDougal, 1998, 256 pp.

MARTINEAU, Harriet. Letters from Ireland. London: John Chapman, 1852, 220 pp.

MOULDEN, John. The Printed Ballad in Ireland: A Guide to the Popular Printing of Songs in Ireland 1760-1920. Ph.D. thesis, Galway: National University of Ireland, 2006, $1129 \mathrm{pp}$. 
Thousands are Sailing: A brief song history of Irish emigration. Portrush: Ulstersongs, 1994, 44 pp.

MORASH, Chistopher. The Hungry Voice: The Poetry of the Irish Famine. Dublin: Irish Academic Press, 1989, 304 pp.

Ó CANAINN, Tomás. Traditional Music in Ireland. London: Routledge \& Kegan Paul, 1978, 145 pp.

Ó GRADA, Cormac. An Drochshaol: Béaloideas agus Amhráin. Baile Átha Cliath: Coiscéim, 1994, ix +104 pp.

Black '47 and Beyond: The Great Irish Famine in History, Economy, and Memory. Princeton: University Press, 2000, 302 pp.

Ó hALLMHURAIN, Gearóid. 'The Great Famine: A Catalyst in Irish Traditional Music Making', pp. 117-130, in Arthur GRIBBEN and Ruth-Anne HARRIS (eds), The Great Famine and the Irish Diaspora in America, Boston: University of Massachusetts Press, 1999.

Ó LAOIRE, Lillis and WILLIAMS, Sean. 'Singing the Famine: Joe Heaney, "Johnny Seoighe" and the Poetics of Performance', pp. 229-247 in Anne CLUNE (ed.), Dear Far-Voiced Veteran: Essays in Honour of Tom Munnelly, Miltown Malbay: Old Kilfarboy Society, 2007.

O'ROURKE, Reverend John. The History of the Great Irish Famine of 1847, With Notices of Earlier Irish Famines. Dublin: McGlashan and Gill, 1875, 551 pp.

O'SUlLIVAN, Donal. Irish Folk Music, Song and Dance [1952]. Cork: The Mercier Press \& the Cultural Relations Committee, 1969, 62 pp.

PETRIE, George. The Ancient music of Ireland, Vol. 1. Dublin: Society for the Preservation and Publication of the Melodies of Ireland, 1855, xx +196 pp.

PÓIRTÉIR, Cathal (ed.). The Great Irish Famine. Cork: Mercier Press, 1995, $283 \mathrm{pp}$.

SHEERAN, Patrick. 'Genius Fabulae: The Irish Sense of Place', Irish University Review, Vol. 18, № 2, Edinburgh: University Press, 1988, pp. 191-206.

SMYTH, Gerry. Music in Irish Cultural History. Dublin: Irish Academic Press, 2009, 196 pp.

THOMSON, George. Island Home: The Blasket Heritage. Dingle: Brandon, 1987, $154 \mathrm{pp}$.

VALLELY, Fintan (ed.). The Companion to Irish Traditional Music. New York: NYUP, 1999, 478 pp.

WHITE, Harry and BOYDELL, Barra (eds.). Encyclopaedia of Music in Ireland. Dublin: UCD Press, 2013, 1152 pp.

WOODHAM-SMITH, Cecil. The Great Hunger -Ireland 1845-1849. London: Penguin Books, 1962, 510 pp.

YOUNG, Arthur, Arthur Young's Tour of Ireland (1776-1779), ed. A. W. HUTTON. London: G. Bell \& Sons, 1892. 